\title{
NOTE ON THE OXFORD LATIN DICTIONARY DEFINITION OF IRRUMO
}

In the second edition of the Oxford Latin Dictionary (2012) an otherwise laudable attempt to be more forthright in defining obscene terms seems to have introduced an error. The word irrumo was defined in the first edition of the dictionary as 'to practise irrumatio on', ${ }^{1}$ which is correct but unilluminating, especially since irrumatio was defined as 'the action of an irrumator'. Irrumator was then defined as 'one who submits to fellatio', which is technically correct, though it suggests a passivity in the action that is not found in the lines from Catullus given as an example of its usage: praesertim quibus esset irrumator | praetor, nec faceret pili cohortem ('not least when said praetor was a fuckface | and didn't give a shit for his poor staffers', Cat. 10.1112). ${ }^{2}$ In this poem Catullus is using the word irrumator as a term of abuse, suggesting that his praetor (in Bithynia) took advantage of his staff members rather than taking care that they too should reap some rewards from the province. Although the literal meaning is secondary to a more metaphorical use here, ${ }^{3}$ the charge is repeated with more direct reference to its sexual usage in Catullus 28.9-10: O Memmi, bene me ac diu supinum | tota ista trabe lentus irrumasti ('Memmius, man, you really reamed me over, | force-fed me slowly with that giant whanger!'). In both cases it is clear that Catullus is an unwilling recipient of the praetor's attentions, and the action is aggressive and demonstrates the latter's ability to dominate his victim. It would not therefore be correct to say that Memmius is 'submitting to fellatio' at the hands, or rather mouth, of Catullus, even metaphorically. The term fellatio, by the way, was not defined in the original

\footnotetext{
${ }^{1}$ P.G.W. Glare (ed,), Oxford Latin Dictionary (Oxford, 1982), 969.

2 Translations of Catullus from Green, Peter, The Poems of Catullus (Berkeley 2005).

${ }^{3}$ K. Quinn, Catullus: The Poems (Bristol 1973), 123.
} 
$O L D$ at all, ${ }^{4}$ and the verb fello had, as its second sense, only 'transf., as a sexual perversion'. The definitions as given therefore seem deliberately obscure, as well as misleading about the roles and intent of the people involved.

In the new edition, this circular and ultimately uninformative set of definitions has been replaced with somewhat more direct terminology, aided by the more widespread understanding of the term 'fellatio' as an English word and changing editorial practices in defining sexual terms. ${ }^{5}$ Now irrumo is defined as 'to practice fellatio on', ${ }^{6}$ with Catullus 16.1 cited as an example; the term 'fellatio' is no longer italicized, indicating that it is being treated as an English, not Latin, word. However, as J.N. Adams makes clear, ${ }^{7}$ the action described by this verb is the opposite of practicing fellatio. Irrumo means to thrust one's penis into another person's mouth, or to force another person to perform fellatio upon oneself. This act of penetration is crucial to the very line cited by the $O L D$, in which irrumabo is paired with pedicabo as an aggressive threat, ${ }^{8}$ used by Catullus to defend against defamation by critics who accuse him, he says, of less than manly behavior: as Williams notes, 'He frames the poem with a famously obscene line in which he threatens (or promises) to penetrate his accusers anally and orally ...

\footnotetext{
${ }^{4}$ The Oxford English Dictionary calls fellatio "modern Latin", formed from fellatus, and it first appears in English in the late nineteenth century, so it is appropriate that the Oxford Latin Dictionary does not have an entry for the word, but by italicizing it in the definition of irrumator the dictionary implies it is a Latin word, not an English term.

${ }^{5}$ This can be seen in new definition of the sexual sense of fello as 'To perform fellatio on'. As well, Google's ngram viewer, though an imprecise tool for judging usage, shows a rise in usage of the term in English around the mid-1970s, after the publication of fascicle IV (1973) of the first edition of the $O L D$, containing irrumo and related words: https://books.google.com/ngrams/graph?content=fellatio\&year_start=1960\&year_end=2008\&co rpus $=15 \&$ smoothing $=3 \&$ share $=\&$ direct_url $=\mathrm{t} 1 \% 3 \mathrm{~B} \% 2 \mathrm{Cfellatio} \% 3 \mathrm{~B} \% 2 \mathrm{Cc} 0$

${ }^{6}$ P.G.W. Glare (ed.), Oxford Latin Dictionary (Oxford, 2012²), 1065.

7 J.N. Adams, The Latin Sexual Vocabulary (Baltimore 1990), 125-30.

${ }^{8}$ K. Quinn, Catullus: The Poems (Bristol, 1973), 143-4.
} 
declaring himself ready, willing, and able to subject them to his phallic power.' ${ }^{9}$ The importance of aggression and the act of penetration for the metaphorical use of the terms, and the connections to broader conceptions of sexuality and masculinity that underlie these types of insults and threats, have been explored in depth in such works as A. Richlin's The Garden of Priapus. ${ }^{10}$ Similarly, irrumatio, which is currently defined by the $O L D$ as 'oral sex, fellatio' is in fact the act of requiring fellatio from another person, not of performing it. Curiously, irrumator, placed in between these two incorrectly defined words, is now more correctly defined as 'a person who receives fellatio', an improvement over the previous edition. However, both irrumo and irumatio should be redefined in such a way as to clarify who is doing what part of the act, and all three definitions should suggest the aggression which is commonly implied by this set of terms in Latin texts.

Thorneloe University at Laurentian

AVEN MCMASTER

amcmaster@laurentian.ca

${ }^{9}$ C.A. Williams, Roman Homosexuality (Oxford, 2010), 182. For more on Catullus' use of the word in poem 16, see Fletcher, K. F. B., 'Catullus' "ATM": The Word Order of Carmen 16.1 and the Roman Hierarchy of Sexual Humiliation', CPh 112.4 (2017), 487-492.

${ }^{10}$ A. Richlin, The Garden of Priapus (Oxford 1992). 